\title{
Relationship between Instructional Leadership and Implementation of Competency-Based Curriculum in Early Years Education in Nairobi City County, Kenya.
}

DOI: https://doi.org/10.47175/rielsj.v2i3.280

\section{| Roselynn Awili, ${ }^{1, *}$ Nyakwara Begi ${ }^{2}$ |}

${ }^{1,2}$ Early Childhood and Special Needs Education, Kenyatta University, Nairobi, Kenya

*roselynn.awili@gmail.com

\section{ABSTRACT}

Globally, learning institutions at primary school level experience a gap in instructional leadership that fosters curriculum implementation. Research has established that those instructional leaders (heads of schools) determine the impact that teaching and learning processes in school has on learners' academic performance. This study was designed to establish the extent of implementation of Competency-Based Curriculum in early years education in public and private schools. The study was also to determine the relationship between instructional leadership and implementation of Competency-Based Curriculum (CBC) in early years education in Kenya. The study was guided by Michael Fullan's Theory of Change. The dependent variable was implementation of Competency-Based Curriculum in early years education while the independent variable was instructional leadership. E-questionnaires and interview schedules were used to collect data which was analyzed using qualitative and quantitative methods. The results showed there was no difference in the implementation of curriculum between private and public primary schools. The relationship between instructional leadership and implementation of competency-based curriculum was significant at 0.05 . The results also indicated that most head teachers focused more on administrative roles than activities that support curriculum implementation. It was therefore recommended that for effective curriculum implementation in early years education, head teachers needed to be intentionally trained on how to support teachers and learners in the related processes

\section{KEYWORDS}

instructional leadership; implementation of Competency-Based Curriculum; early years education; primary schools; Nairobi City County; Kenya

\section{INTRODUCTION}

All over the world, curriculum implementation seems to be a challenge (World Bank, 2011). When curriculum is rolled out effectively in early years education, it lays the foundation to ensure that subsequent educational experiences become successful (Oluoch, 2006). Children gain the required competencies in the classes that come after early years education (Hoy, 2003). According to Blase (1999), head teachers play an important role in ensuring schools have the right resources and guidance to implement curriculum. In order to see improvement in academic performance, head teachers need to observe lessons as taught by teachers and offer feedback on how to make those lessons more learner-centred 
(Hallinger \& Heck, 1996). Therefore, for effective curriculum implementation, the head teachers need to be involved in guiding the teachers through giving instructional responses and advice after observing them teach their lessons.

Teachers are educational facilitators who need motivation and support to implement curriculum effectively. According to Lenardo (2016) and Jansen \& Taylor (2003) when teachers are confident and have ample time to practice and internalize different strategies, they implement curriculum effectively. As instructional leaders, head teachers need to pursue different professional development opportunities to equip themselves and their teachers with best practices in curriculum delivery (Bybee \& McInerney, 1995).

Instructional leadership is an essential ingredient for improving student learning. Ruebling (2004) observed that most schools struggled with students' performance because of behaviour linked to the heads of school. He suggested that for successful implementation of curriculum, heads of schools need to be trained in supporting and monitoring the implementation of curriculum. When learners continue to lag behind in critical aspects like achieving learning goals, it requires educators entrusted with leadership to work together to bridge that gap (Danielson, 2002). Fullan (2017) also emphasized that without the leader's support in setting and implementing systems at school, all other efforts become futile.

In Kenya, most instructional leaders (head teachers) serve as managers. The Kenya Ministry of Science and Technology (1994), states that head teachers are tasked with implementing all decisions at school, supported by the Board of Management (BOM) and the Parents Teachers Association (PTA). These decisions are accompanied with the responsibility to monitor all aspects related to teaching and learning to meet set educational goals. Instructional leaders rise to the headship position through experience and seniority (Metue, 2014).

The role of a head teacher is laid out by the Teachers Service Commission (TSC) as; an accounting officer at the school, an interpreter and implementer of policies and systems related to learning and teacher professional development, an overall supervisor, coordinator and organizer of all activities happening at the learning institution (Nandwah (2011). As part of head teachers' leadership skills, the Total Quality Management (TQM) practices expects them to spearhead learning experiences at school through instructional leadership, shared leadership, planning and implementation of school systems and continuous improvement of the school (Sangeeta \& Banwe, 2004).

\section{Problem Statement}

Instructional leadership is considered one of the main contributors to effective implementation of the Competency-Based Curriculum in early years education. Selfefficacy, problem-solving, collaboration and communication competencies are some of the student gains that learners acquire when a curriculum is implemented effectively. Through setting up systems that support teaching and learning, head teachers can ensure that the learning environment at school fosters holistic growth and development for all learners. In Kenya, different government agencies including the Teachers Service Commission (TSC) and Kenya Education Management Institute (KEMI) have made considerable milestones in supporting instructional leaders (head teachers) to better balance their administrative and instructional roles.

In spite of the efforts made to enhance head teachers' roles as instructional leaders in curriculum implementation, head teachers still struggle to plan and implement some of the systems required for effective implementation of curriculum especially in early years education. A collection of studies has tried to investigate some of the causes and impact of 
ineffective implementation of curriculum. Studies related to Competency-Based Curriculum that were conducted in Nairobi City County majorly looked at teacher-related factors that focused on: availability of teacher guides, insufficient instructional materials, learner preparedness, teacher and learner incentives and attitudes towards curriculum implementation. Given the critical role that instructional leadership plays in curriculum implementation, these studies were a stepping stone that offered insight into the current study. Thus, this study focused on the relationship between instructional leadership and implementation of the Competency-Based Curriculum in early years education.

\section{Objectives of the Study}

1. To establish the extent of implementation of Competency-Based Curriculum in early years education in public and private schools.

2. To find out the relationship between instructional leadership and implementation of Competency-Based Curriculum in early years education.

\section{Research Hypothesis}

Ha1: There is a difference in implementation of Competency-Based Curriculum in early years education between public and private primary schools

Ha2: There is a relationship between instructional leadership and implementation of the Competency-Based Curriculum in early years education

\section{Theoretical Framework}

Michael Fullan's Theory of Change (2003) guided this study. Fullan emphasizes that for effective school reforms and curriculum implementation, the action role is as important as the planning process. It is for this reason that Fullan's theory is referred to as the theory of action; schoolwide practices that bring about systemic change through engaging all the stakeholders involved in the education cycle. The study focused on three of the seven premises that underpin the theory.

In the theory of action, the first premise is motivation. For real change to happen, the whole school community needs to be involved in planning, decision making and implementation to ensure tangible results. Change only happens when motivation is inbuilt into the whole system without which, the rest of the premises will be dysfunctional. Motivation requires that shared leadership is eminent, feedback giving mechanisms are established and adequate resources availed. This study focused on supporting instructional leadership as a motivation to school leaders to effectively implement CBC in early years education.

The next basic premise is 'learning in context'. School heads around the world face similar challenges. There is need to build platforms and opportunities to share some of these experiences amongst educators, including the solutions thereof. This will provide a pool of knowledge that can be contextualized and rightly adapted to different unique school settings. The principle of globally informed and locally adapted is critical in ensuring that each school head teacher is selecting solutions applicable to their school communities. Systemic knowledge change requires specific displacement of existing structures, processes and norms while modelling the expected behaviour change by other successful implementers. This study focused on establishing the extent of curriculum implementation through examining the head teachers' role in observing teachers teach and offering them feedback. 
To be effective, the above-mentioned premises require reflective action. Reflective action, as described by Fullan, is the principle of intentionally developing and/or reviewing a shared vision while optimizing for ownership of the envisioned change. It is a quality process that requires a growth mindset in behaviour and actions of the school community. The reflective practice is aligned to Dewey's work that intimates the immense learning we get from purposefully thinking about our actions versus merely doing the actions.

The selected premises in the theory of action are clearly outlined and align to this study. They explicitly bring out the factors to consider for a successful school reform such as curriculum implementation.

\section{RESEARCH METHODS}

\section{Research Design}

This study used a correlation research design. A correlation research design involves measurement of the scores of two variables without manipulation to establish if a relationship exists (Creswell, 2014). The design was used to try and establish if a relationship existed between instructional leadership and implementation of CompetencyBased Curriculum in early years education.

\section{Variables}

The dependent variable in this study was implementation of the Competency-Based Curriculum in early years education. This was measured using e-questionnaires for grade three teachers. Teachers' abilities to implement the CBC in early years education was assessed to test skills in: lesson planning, content selection, teaching-learning methodology, actual lesson presentation, lesson evaluation and recording.

The independent variable was instructional leadership: head teachers' role in supporting curriculum implementation at school. It was measured by the head teachers' ability to set teaching and learning systems that support curriculum implementation including; observing teachers teach lessons, giving feedback related to lesson delivery and availing professional opportunities for teachers.

\section{Location of the Study and Target Population}

This research was conducted in Embakasi Central, Nairobi City County. Embakasi Central has five wards and is located on the eastern side of the central business district of Nairobi City County with an approximate population of 185,948 and an area coverage of approximately 14.30 square kilometres.

Embakasi central is one of the most densely populated constituencies in Nairobi City County (National Census 2009). Thus, available educational resources are inadequate which leads to children leaving school without acquiring the right competencies needed to thrive and succeed in life. They therefore end up with low self-esteem, poor communication and problem-solving skills and engage in crime at an early age (Tonui, 2014).

The target population was head teachers and grade three teachers employed both in public and private primary schools in Embakasi Central sub-county, Nairobi City County. A total of 76 primary schools exists in Embakasi Central, Nairobi City County; 51 private and 25 public primary schools. $15 \%$ of the total number of teachers and head teachers were sampled to participate in the study. 


\section{Sampling Technique and Sample Size}

Embakasi Central sub-county, Nairobi City County has an economically heterogeneous population. Purposive sampling was therefore used to select it. Participants of the study came from schools in the informal settlements of the locality plus schools from the up estates to provide the study with different socio-economic backgrounds.

Anderson (1998) suggests that for a descriptive study $10-20 \%$ of a study population is adequate. As such, stratified random sampling was used to select the primary schools which were stratified as either public or private schools.

Grade three was also purposively sampled since it is a critical transition stage from lower primary to upper primary. Acquisition of competencies in this stage by learners lays a foundation for learning in subsequent grade levels.

The head teachers and grade three teachers were automatically sampled. For every school that was selected to participate in the study, the grade three teachers were selected as well. The available head of school (head teacher, senior teacher, deputy head teacher, principal or school director) filled the head teachers' e-questionnaire

The study sample included 12 primary schools: four public and eight private schools. The sample of teachers was 12; 4 from public primary schools and 8 from private. The sample of head teachers was also 12; 4 from public primary schools and 8 from private schools selected to participate in the study.

\section{Research Instruments and Pilot Study}

The instruments used for data collection were e-questionnaires for grade three teachers and e-questionnaires for head teachers. The researcher also used interview schedules to collect data from the selected head teachers and teachers.

The grade three e-questionnaire was used to assess the teachers' abilities to implement the $\mathrm{CBC}$ in early years education. It consisted of five sections to collect: general demographic information and items that measure curriculum implementation. The equestionnaire was shared with the selected grade three teachers as a soft copy Google form to fill and submit online.

The e-questionnaire for school head teachers was used to collect data on the role of head teachers in curriculum implementation. The head teachers filled in the e-questionnaires by responding to the items stated therein. The e-questionnaire was analyzed using percentages and frequencies.

Document analysis was conducted to obtain information from lesson plans. The lesson plans were checked to confirm; availability, planning of lessons in accordance to curriculum designs, selection of learning experiences and teacher remarks. Grade three teachers shared photos of their lesson plans virtually with the researcher.

Interview schedules were used to collect data from both teachers and head teachers. The researcher called the participants via phone and used interview questions to collect data regarding the extent of $\mathrm{CBC}$ implementation in early years and instructional leadership.

The general demographic information was analyzed using descriptive methods (frequencies and percentages).

Items that measure curriculum implementation were used to determine teachers' abilities in implementation of curriculum. 'Mostly' was interpreted as skill developed and quantified as 3. 'Sometimes' was interpreted as skill partly evident and quantified as 2. 'Rarely' was translated as skill not developed and quantified as 1 . A total of 23 items were selected and each item was worth 3 points out of the total 69. A teacher's effectiveness in CBC implementation was gauged by summing up the times he/she scored 'Mostly'. 
The e-questionnaires for grade three teachers and e-questionnaires for head teachers were tested in two primary schools; one public and the other private school. The final study excluded these two pilot schools. The pilot allowed for paraphrasing and clarifying some of the items that appeared ambiguous to the respondents.

\section{Validity}

Orodho (2005) defines validity of content as the precision applied to a variety of a concept's measures. The research supervisor for this study, offered content validity by assistance in clarifying the instrument items. Item analysis also further supported validity by ensuring all variables and objectives of the study were covered.

\section{Reliability}

Internal consistency reliability method was used to test instrument reliability for the study to ensure that the results were consistent across items. Reliability co-efficiency was calculated using Guttman Split-Half test.

\section{Data Collection and Analysis}

Data was collected in three phases:

\section{Phase One: Administration of the E-questionnaire for Teachers}

Data on effective implementation of curriculum was collected from grade three teachers using an e-questionnaire. The guide measured the teachers' basic knowledge and skills in implementing the CBC in early years education. The teachers' competency in curriculum implementation was determined after teachers self-reported their classroom teaching and learning experiences through the e-questionnaire. Teachers who reported having the required documents and who completed the selected activities received a 'Mostly'. Teachers who had the required documents but partly completed the required activities received a 'Sometimes'. Those without the required documents and indicated not completing the selected activities received a 'Rarely'. A teacher's overall effectiveness to implement curriculum was determined by the availability of documents and the count of times teachers indicated they completed the selected activities.

The researcher guided teachers to complete the e-questionnaire about their teaching practice from beginning to end. Each e-questionnaire filling exercise lasted for approximately 30-35 minutes. There was one e-questionnaire per teacher selected for the study.

\section{Phase Two: Administration of the E-Questionnaire to Head Teachers}

The e-questionnaires were administered to head teachers of the sampled schools during the school lock-down period in the advent of covid-19. The available school leader filled out the e-questionnaire; either the principal, head teacher, deputy head teacher or school director. The e-questionnaire was used to collect data on the head teacher's role in curriculum implementation. The head teachers were expected to indicate which curriculum implementation roles they support the school in: encouraging teachers to pursue professional development opportunities, observing teachers teach lessons and providing feedback to teachers on the lessons observed. This information was helpful in establishing how the variable influences $\mathrm{CBC}$ implementation in early years education.

\section{Phase Three: Document Analysis for Grade Three Teachers}


The document analysis was conducted on grade three teachers. This was done to ascertain the availability of lesson plans and to confirm their compliance to guidelines as per the curriculum designs. The researcher checked for updated lesson plans that reference the current KICD curriculum designs. This information was helpful in identifying whether teachers have the most current competencies in lesson planning for CBC.

\section{Data Analysis}

Data collected from e-questionnaires for teachers and head teachers and document analysis was sorted out, cleaned and coded to identify common themes and meanings. Thereafter, the data was entered into the Statistical Packages for Social Sciences (SPSS) to yield different means, standard deviation and percentages. Descriptive and inferential statistics were used to analyze the data. Inferences, percentages and means were calculated to represent descriptive statistics. Inferential statistics was used for $\mathrm{H}_{1}$ t-test while Pearson correlation was used to test $\mathrm{HO}_{2}$. Presentation of the results from data analysis was done in tables and figures. These were organized in accordance with the objectives and hypotheses of the study.

\section{Logistical and Ethical Considerations}

An introductory letter was acquired from the Kenyatta University Graduate School. Kenyatta University Ethics and Review provided clearance to proceed with the study. A research permit was also obtained from NACOSTI.

Authorization to access the schools selected for the study was pursued from the Regional Director of Education's office and permission to administer the e-questionnaires to grade three teachers and head teachers was sought through a consent letter signed by study participants.

For confidentiality purposes, the respondents were assigned codes. The research instruments did not require them to write or offer their names. Under no circumstances was the information obtained used against the study respondents.

The researcher explicitly communicated the purpose of study to the respondents and sought informed consent from them before administering the instruments.

Community in this study referenced parents, learners, teachers, head teachers, curriculum support officers and schools in Nairobi City County. The findings of the study may be of great value and insight to the community and recommendations on the implementation of curriculum in Nairobi City County may also be drawn from this study.

\section{RESULTS AND DISCUSSION \\ Extent of Curriculum Implementation in Early Years Education}

The first objective was stated as:

\section{Objective 1: To establish the extent of implementation of Competency-Based Curriculum in early years education in public and private schools.}

The researcher started by looking at the level of planning the learning activities, the actual implementation of those learning experiences and their evaluation. The head teachers' extent of curriculum implementation was self-reported through ascertaining the systems in place to ensure teachers were planning, implementing and evaluating curriculum activities and learning experiences.

To verify the extent of curriculum implementation in early years, teachers and head teachers were expected to indicate the frequency of how often they plan, follow their plans and conduct evaluation activities related to curriculum implementation. The results are as shown in Table 1 below. 
Table 1. Frequency Distribution on Teachers Implementation of Competency-Based Curriculum

\begin{tabular}{llrr}
\hline Implementation of CBC & Scale & Frequency & \multicolumn{1}{c}{$\%$} \\
\hline \multirow{3}{*}{ Plan for all content } & Never & 0 & $0.0 \%$ \\
& Sometimes & 6 & $50.0 \%$ \\
& Mostly & 6 & $50.0 \%$ \\
Set clear learning outcomes & Never & 1 & $8.3 \%$ \\
& Sometimes & 3 & $25.0 \%$ \\
& Mostly & 8 & $66.7 \%$ \\
Conduct needs assessment & Never & 0 & $0.0 \%$ \\
& Sometimes & 8 & $66.7 \%$ \\
Trained in implementation of CBC & Mostly & 4 & $33.3 \%$ \\
& Never & 4 & $33.3 \%$ \\
& Sometimes & 0 & $0.0 \%$ \\
Has access to teaching learning resources & Mostly & 8 & $66.7 \%$ \\
& Never & 4 & $33.3 \%$ \\
& Sometimes & 0 & $0.0 \%$ \\
School has a platform for giving feedback & Mostly & 8 & $66.7 \%$ \\
& Never & 5 & $41.7 \%$ \\
& Sometimes & 0 & $0.0 \%$ \\
& Mostly & 7 & $58.3 \%$ \\
\hline
\end{tabular}

The results showed in all schools, teachers were planning for content and conducting needs assessments to a certain level. The data collected from the schools indicated that this could be due to the requirement by the government to have of all grade three teachers attend $\mathrm{CBC}$-related training.

To further understand the extent of implementation of Competency-Based Curriculum in early years, mean scores in teachers' implementation of Competency-Based Curriculum researcher were analyzed and summarized as presented in Table 2 below.

Table 2. Mean Scores in Teachers' Implementation of Competency-Based Curriculum

\begin{tabular}{lccccr}
\hline Implementation of CBC & N & Minimum & Maximum & Mean & $\begin{array}{c}\text { Std. } \\
\text { Deviation }\end{array}$ \\
\hline Plan for all content & 12 & 2 & 3 & 2.50 & .522 \\
Set clear learning outcomes & 12 & 1 & 3 & 2.58 & .669 \\
Conduct needs assessment & 12 & 2 & 3 & 2.33 & .492 \\
Trained in implementation of CBC & 12 & 1 & 3 & 2.33 & .985 \\
$\begin{array}{l}\text { Has access to teaching learning } \\
\text { resources }\end{array}$ & 12 & 1 & 3 & 2.33 & .985 \\
$\begin{array}{l}\text { School has a platform for giving } \\
\text { feedback }\end{array}$ & 12 & 1 & 3 & 2.17 & 1.030 \\
\hline Valid N (listwise) & 12 & 1 & 3 & 2.37 & \\
\hline
\end{tabular}

The above table indicates that the mean scores in implementation of Competency-Based Curriculum in early years education ranged from 2.17- 2.58. Close examination of the results also reveals that the implementation of the curriculum ranged from 'sometimes' to 'mostly'. The overall mean score in implementation of Competency-Based Curriculum in early year education was 2.37. The result implies that the extent of implementation of Competency-Based Curriculum in early years education was sometimes. 
To establish the difference in the extent of implementation of CBC curriculum in early years between public and private schools, the following null hypothesis was generated and tested.

H01: There is no difference between implementation of Competency-Based Curriculum in public and primary schools

The overall mean scores were calculated and presented as shown in Table 3 below.

Table 3. Overall Mean Scores in Teachers' Implementation of Competency-Based Curriculum between Teachers in Public and Private Primary Schools.

\begin{tabular}{llcccc}
\hline & Type of school & N & Mean & $\begin{array}{c}\text { Std. } \\
\text { Deviation }\end{array}$ & $\begin{array}{c}\text { Std. Error } \\
\text { Mean }\end{array}$ \\
\hline Implementation of & Public & 4 & 2.63 & .551 & .275 \\
CBC & Private & 8 & 2.25 & .512 & .181 \\
\hline
\end{tabular}

The results from the above table show that the mean scores in teachers' implementation of Competency-Based Curriculum for public schools was 2.63, while that of teachers in private schools was 2.25. The results imply that implementation of Competency-Based Curriculum in public schools was higher than that of private schools. Analysis of the interviews indicated that teachers from public schools received support related to CBC implementation than teachers from private schools as reported in the interviews below:

The Curriculum Support Officer assigned by TSC to my school comes every month to review my progress in how I conduct the CBC lessons. Whenever I have challenges, I note them down and ensure to talk through the challenges with him so that I can proceed after his affirmation. Teacher public primary school 2.

There is a group of CBC trainers who are available to train my teachers. The problem is that they charge so much yet I do not have such money to sponsor my teachers to attend. So, I encourage teachers to find their own means to update themselves on conducting CBC lessons. At some point, I know they will all be at per with the other schools. Head teacher private primary school 5.

The researcher used t-test to determine whether there was a difference in implementation of early years curriculum between public and private schools and the results are presented in Table 4 below.

Table 4. Independent Samples of t-test for Equality of Means by School Type t-test for Equality of Means

\begin{tabular}{llcccc}
\hline & & T & $\begin{array}{c}\text { Sig. (2- } \\
\text { tailed) }\end{array}$ & $\begin{array}{c}\text { Mean } \\
\text { Difference }\end{array}$ & $\begin{array}{l}\text { Std. } \\
\text { Difference }\end{array}$ \\
\hline Implementation of CBC & $\begin{array}{l}\text { Equal } \\
\text { variances } \\
\text { assumed }\end{array}$ & 1.169 & .269 & .375 & .321 \\
& & & & \\
\hline & $\begin{array}{l}\text { Equal } \\
\text { variances } \\
\text { not } \\
\text { assumed }\end{array}$ & 1.138 & .301 & .375 & .329 \\
& & & & \\
\hline
\end{tabular}

Table 4.5 shows that the difference between the mean scores for both private and public schools is .375 with a p-value of .269. These results imply that the difference in 
implementation of curriculum in early years between public and private schools was not significant. The null hypothesis was therefore accepted. This means that the implementation of $\mathrm{CBC}$ between teachers in public and private schools was the same.

The current study recorded that $100 \%$ of public schools reported attendance to professional development workshops that were sponsored by the government. On the other hand, private schools were required to pay for CBC trainings. Thus, their implementation of curriculum became impaired. These findings are similar to reports by Burgess, Patterson and Robertson (2010) who found out that the extent of curriculum implementation in early years varies across school types. Public schools implemented curriculum more effectively due to higher government support.

Interview results from the current study revealed that Curriculum Support Officers from TSC (Teachers Service Commission) were assigned to monitor the implementation of CBC in public schools. As a result, the extent of curriculum implementation in public schools was higher than private schools. Meyer \& Gordon (2014) found similar results which indicated that the involvement of policies by state to support curriculum implementation in public schools served as a driver to ensuring the curriculum is implemented effectively.

However, a study conducted in Philippines by Leonardo (2016) on challenges of curriculum implementation for elementary, secondary and kindergarten learners discovered that private schools outperformed public schools in curriculum implementation as they were directly supported by the owners who invested in school systems. Leonardo's report pointed out that most government schools lacked consistent supervision and resourcing to ensure effective curriculum implementation. The inconsistency in these two studies could be due to individual school owners' commitment and prioritization of school management in the Philippines as compared to the staggered implementation of a new curriculum in Kenya where CBC-related trainings give priority to public schools.

\section{Instructional Leadership and Implementation of Curriculum in Early Years}

To explore if the role of the head teacher in supporting teaching and learning systems in the school influenced curriculum implementation, the objective was stated as:

\section{Objective 2: To find out the relationship between instructional leadership and implementation of Competency-Based Curriculum in early years education.}

The researcher sought to establish the access and availability of professional development opportunities related to $\mathrm{CBC}$; plus, additional support available in the school for lesson observation and feedback giving. Table 5 below shows the results.

Table 5. Frequency Distribution on Teachers' Instructional Leadership

\begin{tabular}{llrr}
\hline Instructional Leadership & Scale & Frequency & \% \\
\hline \multirow{2}{*}{ Provision of professional development } & Never & 1 & $8.3 \%$ \\
opportunities & Sometimes & 4 & $33.3 \%$ \\
& Mostly & 7 & $58.3 \%$ \\
Attending CBC professional development & Never & 1 & $8.3 \%$ \\
opportunities & Sometimes & 8 & $66.7 \%$ \\
& Mostly & 3 & $25.0 \%$ \\
Head teacher observing lessons & Never & 5 & $41.7 \%$ \\
& Sometimes & 2 & $16.7 \%$ \\
\multirow{2}{*}{ Feedback covers quality of the lesson } & Mostly & 5 & $41.7 \%$ \\
& Never & 6 & $50.0 \%$ \\
& Sometimes & 0 & $0.0 \%$ \\
& Mostly & 6 & $50.0 \%$ \\
\hline
\end{tabular}


Table 5 shows that more that $90 \%$ of head teachers provide opportunities from CBCrelated training which was equally attended by more than $90 \%$ of teachers. $50 \%$ of the head teachers struggled to find time for lesson observation and feedback giving. The results imply that head teachers focus more on administrative roles than instructional leadership related to CBC implementation.

After assessing the head teachers' instructional leadership competencies, the researcher analyzed and summarized the mean scores in instructional leadership as presented in Table 6 below.

Table 6. Mean Scores in Instructional Leadership

\begin{tabular}{|c|c|c|c|c|c|}
\hline $\begin{array}{l}\text { Instructional } \\
\text { Leadership }\end{array}$ & $\mathbf{N}$ & Minimum & Maximum & Mean & $\begin{array}{c}\text { Std. } \\
\text { Deviation }\end{array}$ \\
\hline $\begin{array}{l}\text { Provision professional } \\
\text { development } \\
\text { opportunities }\end{array}$ & 12 & 1 & 3 & 2.50 & .674 \\
\hline $\begin{array}{l}\text { Attending CBC } \\
\text { professional development } \\
\text { opportunities }\end{array}$ & 12 & 1 & 3 & 2.17 & .577 \\
\hline $\begin{array}{l}\text { Head teacher observing } \\
\text { lessons }\end{array}$ & 12 & 1 & 3 & 2.00 & .953 \\
\hline $\begin{array}{l}\text { Feedback covers quality } \\
\text { of the lesson }\end{array}$ & 12 & 1 & 3 & 2.00 & 1.044 \\
\hline Valid N (listwise) & 12 & 1 & 3 & 2.17 & \\
\hline
\end{tabular}

The above table indicates that the overall mean in instructional leadership in early years education was 2.17. The result implies that the use of instructional leadership in the implementation of CBC in early years education was 'sometimes'.

To find out if there was a correlation between instructional leadership and implementation of curriculum in early years, the following null hypothesis was formulated and tested:

$\mathrm{HO}_{2}:$ There is no significant relationship between instructional leadership and implementation of $\mathrm{CBC}$ in early years education

The overall mean scores were calculated and the results presented as shown in Table 7 below.

Table 7. Overall Mean Scores in Instructional Leadership

\begin{tabular}{lrrr}
\hline & Mean & Std. Deviation & N \\
\hline Implementation of & 2.38 & .532 & 12 \\
CBC & 2.17 & .587 & 12 \\
Instructional leadership & &
\end{tabular}

The results from the above table shows that the overall mean score in instructional leadership was 2.17. The results imply that instructional leadership in primary schools was implemented 'sometimes'. Analysis of the interview results indicated that this could be attributed to the fact that most head teachers view their role as general overseer of the school and not specifically engagement with how teachers teach or set up systems to support CBC implementation.

Pearson correlation was used to determine whether there was a relationship between instructional leadership and implementation of CBC curriculum in early years education as shown in Table 8 below: 
Table 8. Relation between Instructional Leadership and Implementation of Competency-Based Curriculum

\begin{tabular}{|c|c|c|c|}
\hline & & $\begin{array}{c}\text { Implementation } \\
\text { of CBC }\end{array}$ & $\begin{array}{c}\text { Instructional } \\
\text { leadership }\end{array}$ \\
\hline \multirow{4}{*}{$\begin{array}{l}\text { Implementation of } \\
\text { CBC }\end{array}$} & Pearson Correlation & 1 & $.654^{*}$ \\
\hline & Sig. (2-tailed) & & .021 \\
\hline & $\mathrm{N}$ & 12 & 12 \\
\hline & Pearson Correlation & $.654^{*}$ & 1 \\
\hline \multirow[t]{2}{*}{ Instructional leadership } & Sig. (2-tailed) & .021 & \\
\hline & $\mathrm{N}$ & 12 & 12 \\
\hline
\end{tabular}

Table 8 shows that the correlation between instructional leadership and implementation of Competency-Based Curriculum was .654 with a p-value of .021. The results imply that the correlation between instructional leadership and implementation of Competency-Based Curriculum was strong. The results also indicate that the relationship between instructional leadership and implementation of $\mathrm{CBC}$ was significant. The null hypothesis was therefore rejected and its alternative accepted.

The current study findings indicate that instructional leadership greatly influences the implementation of CBC curriculum. From the study, teachers who received head teachers' support to pursue CBC-related trainings showed better planning and implementation than those who received $\mathrm{n}$ to minimal support. These findings are consistent with study findings by Danielson (2002) who reported that the head teachers' support in curriculum implementation is the solution to improving learner achievement.

In a study by Taole (2013) on teachers' conceptions of the curriculum review process, he indicated that $87 \%$ of head teachers were willing to allow teachers in their schools attend professional development ventures to improve on their curriculum delivery. However, head teachers were more often not sure how to support the teachers in the actual implementation at the classroom level and therefore did not get involved as much. Taole's study finding concur with the current study as $91.7 \%$ of head teachers provided their teachers with professional development opportunities. The interview results however revealed that they were not sure on how to support the teachers in the actual teaching activities related to $\mathrm{CBC}$ curriculum implementation.

\section{CONCLUSION}

The first objective was to establish the extent of implementation of Competency-Based Curriculum in early years education between public and private schools. Findings indicated that the extent of implementation of Competency-Based Curriculum in early years education was average at an overall mean score of 2.37. The results also showed that the implementation of Competency-Based Curriculum in public schools was higher than that of private schools. The conclusion thereof, was that, there was no difference in the implementation of Competency-Based Curriculum between public schools and private schools.

The second objective was to find out the relationship between instructional leadership and implementation of Competency-Based Curriculum in early years education. Findings revealed that the use of instructional leadership in the implementation of CBC in early years education was average at an overall mean score of 2.17. This is because most head teachers viewed their role as more administrative than supporting learning systems. The relationship between instructional leadership and implementation of $\mathrm{CBC}$ was not 
significant at a correlation of .654 and p-value of .21. In conclusion, instructional leadership did not influence the implementation of CBC in early years education.

\section{ACKNOWLEDGMENT}

Sincere gratitude to God Almighty for granting perfect health and wisdom to conduct this research. This research is dedicated to the researchers' families who offered their encouragement, patience, moral and social support throughout the research period. All the institutions who participated in this study are also acknowledged: Kenyatta University, public and private primary schools in Embakasi Central, Nairobi, Kenya.

\section{REFERENCES}

Blasé, J. \& Blasé J. (1999). Principals' instructional leadership and teacher development: Teachers' perspectives. Educational Administration Quarterly, 35 (3), 349-378.

Bybee, W., \& McInerney, J. D. (1995). Biological Sciences Curriculum Study: Colorado Springs, Colorado

Creswell, J. D. (2012). Research design: Qualitative and quantitative approaches. SAGE, London.

Fullan, M. G. (2017). The New Meaning of Educational Change. (4th ed). London

Fullan, M. G. (2003). Change Forces. Probing the depths of educational reform. London: Falmer press.

Hallinger, P. \& Heck, R. (1996). Reassessing the principal's role in school effectiveness: A review of the empirical research, 1980-1995. Educational Administration Quartelry,32 (1), 5-44.

Hoy, A. \& Hoy, W. (2003). Instructional leadership: A learning-centered guide. Boston, MA: Allyn \& Bacon.

Jansen, J. \& Taylor, P. (2003). Changing Curriculum: Studies on Outcomes-based Education in South Africa. Kenwyn: Juta \& Co.

Lenardo, F. C. (2016). A case study of teachers' implementation of curriculum innovation in English language teaching in Turkish primary school education. Teaching and Teacher Education, 24, 1859-1875

Metue, L. N. (2014). Influence of head teachers' instructional supervision practices on curriculum implementation in Isinya Sub County, Kenya. University of Nairobi: Nairobi

Meyer, A. \& Gordon, D. (2014). Universal design for learning: theory and practice. http://udltheorypractice.cast.org.

Ministry of Education (1994). Education in Kenya: Information handbook. Nairobi: Jomo Kenyatta Foundation.

Nandwah, I. (2011): Preparation and Development of public secondary school principals in Kenya. International Journal of Humanities and Social Science Vol. 1 No. 9.

Oluoch, P. G. (2006). Essentials of Curriculum Development (3rdEdition). Nairobi: Longhorn Publishers.

Sangeeta, S. \& Banwe, D.K (2004) Conceptualizing total quality management in higher education. The TQM Magazine, Vol. 16 (2); Emerald Group Publishing Limited.

World Bank (2011). A regional exploration of pathways toward harmonization of mathematics \& science curriculum in the East African Community; Discussion Paper, Washington D.C: World Bank 